Diabetologia 9, $140-144(1973)$

(C) by Springer-Verlag 1973

\title{
Hypophysis and Function of Pancreatic Islets
}

\section{The Effect of Substitution with Growth Hormone and Corticotrophin on Insulin Secretion and Biosynthesis of Proinsulin and Insulin in Isolated Pancreatic Islets of Hypophysectomized Rats ${ }^{* *}$}

\author{
H. Schatz*, N. Katsilambros*, M. Hinz, K.H. Voigt, C. Nierle and E.F. Pfeiffer \\ Department of Endocrinology and Metabolism, Center of Internal Medicine and Pediatrics, University of Ulm, \\ Ulm/Donau, Germany
}

Received: October 30, 1972, accepted: December 14, 1972

\begin{abstract}
Summary. Hypophysectomized rats were substituted with varying doses of human or porcine growth hormone (GH) as well as with ACTH for 6 or 12 days. Hypophysectomy was performed in animals of 80 or $170 \mathrm{~g}$ body weight either 12 or 4 weeks prior to the onset of the therapy. Increase in weight and the width of the epiphyseal cartilage were determined, insulin secretion and biosynthesis of proinsulin and insulin were investigated in isolated pancreatic islets of the animals. - No differences were found between the effects of human and porcine GH preparations. Weight gain was similar in rats which had been hypophysectomized at a weight of $80 \mathrm{~g}$ either 12 or 4 weeks prior to the substitution. Secretion and biosynthesis of insulin which were both found to be reduced in isolated islets of untreated, hypophysoctomized rats, were improved or normalized after substitution with $\mathrm{GH}$
\end{abstract}

(1 $\mathrm{mg} / \mathrm{kg} /$ day) for 12 days. On the other hand, a therapy with $\mathrm{GH}$ for 6 days, even in tenfold daily dose $(10 \mathrm{mg} / \mathrm{kg})$, was ineffective in all rats which had been hypophysectomized at a weight of $80 \mathrm{~g}$. Normalisation of lowered levels of blood sugar was the only positive effect observed after an administration of ACTH for 6 or 12 days. - It appears from our findings that, in contrast to the administration of ACTH, GH given to hypophysectomized rats for a longer period in relatively low doses may normalize both reduced secretion and biosynthesis of insulin.

Key words: Hypophysectomy, growth hormone, corticotrophin, insulin secretion, biosynthesis of proinsulin and insulin, protein synthesis, isolated pancreatic islets, epiphyseal cartilage of the tibia.
Hypophysectomy in rats results in both reduced secretion and biosynthesis of proinsulin and insulin from their isolated pancreatic islets as shown previously [13]. These defects, however, depend on age or weight of the animals as well as on the interval following hypophysectomy. This paper deals with the influence of duration and doses of substitution with growth hormone and corticotrophin (ACTH) on insulin secretion and synthesis of proinsulin and insulin in vitro in isolated pancreatic islets of hypophysectomized rats. As parameters of the hormonal actions in vivo, body weight, width of the epiphyseal cartilage and blood glucose were evaluated. In addition to growth hormone, ACTH was chosen as second hormone of the anterior pituitary gland since it has been described as being effective on secretion of instulin in vitro [13]. Furthermore - in contrast to thyrotrophin - a highly purified form of this hormone was available in the amounts required for an administration of longer duration.

\section{Material and Methods}

Rats, experimental conditions and hypophysectomy were the same as described before (13). From a total of 55 successfully hypophysectomized rats, 38 animals were

* Alexander von Humboldt-Fellow 1970-1972. H.S. was on leave from the 2nd Medical Clinic, University of Vienna, Austria.

** Supported by Doutsche Forschungsgemeinschaft, Bonn-Bad Godesberg, SFB Ulm 87, Proj. 11. submitted to substitution therapy prior to investigation. Table 1 gives the characterisation and distribution of the 38 rats into 4 groups, which correspond to the 4 groups of part I.

Growth hormone was prepared in our own laboratory from pituitary glands frozen at $-25^{\circ} \mathrm{C}$ immediately following removal ${ }^{1}$. Rats of group $I$ and II received human growth hormone [15], rats of group III and IV growth hormone of porcine origin [16]. In a modified tibia test (Baetzner, Fehm, Voigt, Schleyer and Pfeiffer, 1972), both growth hormone preparations proved to be of approximately the same biologic activity. In this test, the maximum effects were observed with a daily dose of $1 \mathrm{mg} / \mathrm{kg}$ body weight. Growth hormone was injected intraperitoneally in daily doses of 1 or $10 \mathrm{mg} / \mathrm{kg}$ for 6 or 12 days. From 3 animals receiving $25 \mathrm{mg} / \mathrm{kg} / \mathrm{day}, 2$ were found dead $12 \mathrm{~h}$ after the first injection.

Corticotrophin (porcine ACTH (1-39), Isactid $\odot$, Ferring Arzneimittel GmbH, Düsseldonf, Germany, $1 \mathrm{mg} \triangleq$ $150 \mathrm{mU}$ ) was administered intraperitoneally in a total daily dose of $3 \mathrm{U} / \mathrm{kg}$ body weight. This hormone was injected twice daily for 6 or 12 days (table 1).

Both hormones were administered in $0.5 \mathrm{ml}$ of phosphate buffer, $0.1 \mathrm{M}, \mathrm{pH} 6.6$.

In addition to the determination of the weight, the width of the epiphyseal cartilage of the tibia was estimated in rats of group III according to Baetzner et al. [1].

Serum glucose was determined by the hexokinase method [17], using the Biochemica test combination (Boehringer Mannheim, Germany).

For the studies of insulin secretion batches of 5 isolated pancreatic islets each were incubated for $1 \mathrm{~h}$ in $1 \mathrm{ml}$ of buffered medium at glucose concentrations of 50 and $300 \mathrm{mg} \%$. Secretion of insulin was also determined during. the $3 \mathrm{~h}$ incubation period carried out to study the synthesis

1 Human as well as porcine growth hormone was prepared and kindly donated by Dr. M. Schleyer. 
of insulin. Biosynthesis of insulin was estimated from the incorporation of ${ }^{3} \mathrm{H}$-leucine into the proinsulin and insulin fraction of 25 islets each during an incubation period of $3 \mathrm{~h}$ at 50 or $300 \mathrm{mg} \%$ glucose. The isolation of the pancreatic islets and the studies on secretion and biosynthesis of insulin were performed exactly as described elsewhere [13]. All experiments were started at $8.00 \mathrm{~h}$ on the morning following the day of the last hormone injection.

\section{Results \\ Growth}

Substitution with growth hormone increased body weight in all 4 groups of hypophysectomized rats (Table 1). In this respect, the interval following hypophysectomy (12 or 4 weeks) had no particular influence provided that the animals were of the same weight (ca. $80 \mathrm{~g}$ ) at the term of hypophysectomy. On the other
Blood glucose (mean values of rats from all 4 groups $\pm \mathrm{SEM}$ ) in intact controls amounted to $113.6 \mathrm{mg} \%$ 4.0. Following hypophysectomy, it was significantly $(p<0.01)$ reduced to $95.4 \mathrm{mg} \% \pm 5.6$. With growth hormone, a normalisation was obtained only after treatment for 12 days $(113.4 \mathrm{mg} \% \pm 8.9)$. Administration of ACTH was also effective $(106.0 \pm 7.3)$.

\section{Insulin secretion}

At $50 \mathrm{mg} \%$ glucose, insulin levels determined in the media after incubation of batches of 5 isolated islets each were found to be within the same range in all groups and subgroups $(60-80 \mu \mathrm{U} / \mathrm{ml})$. Differences between the subgroups existed, however, in the secretion of insulin after stimulation with $300 \mathrm{mg} \%$ glucose (Fig. 1): In rats which had been hypophysec-

Table 1. Mean weight and ime of onset, duration and dose of substitution therapy in 4 groups of hypophysectomized rats

\begin{tabular}{|c|c|c|c|c|c|c|c|}
\hline \multirow[b]{2}{*}{ group } & \multirow{2}{*}{$\begin{array}{l}\text { interval between } \\
\text { hypophysectomy } \\
\text { and onset of } \\
\text { therapy (weoks) }\end{array}$} & \multirow[b]{2}{*}{ therapy } & \multirow{2}{*}{$\begin{array}{l}\text { duration of } \\
\text { therapy } \\
\text { (days) }\end{array}$} & \multirow{2}{*}{$\begin{array}{l}\text { daily dose } \\
\text { GH: mg/kg } \\
\text { ACTH: } \\
\mathrm{mU} / \mathrm{kg}\end{array}$} & \multicolumn{2}{|c|}{ weight (g) } & \multirow[b]{2}{*}{$\mathrm{n}$} \\
\hline & & & & & $\begin{array}{l}\text { prior to } \\
\text { therapy }\end{array}$ & $\begin{array}{l}\text { after } \\
\text { therapy }\end{array}$ & \\
\hline $\mathrm{I}$ & 12 & $\begin{array}{l}\text { H-GH } \\
\text { ACTH }\end{array}$ & $\begin{array}{l}6 \\
6\end{array}$ & $\begin{array}{l}1 \\
3\end{array}$ & $\begin{array}{l}84 \\
87\end{array}$ & $\begin{array}{l}98 \\
86\end{array}$ & $\begin{array}{l}6 \\
4\end{array}$ \\
\hline II & 4 & $\begin{array}{l}\text { H-GH } \\
\text { ACTH }\end{array}$ & $\begin{array}{l}6 \\
6\end{array}$ & $\begin{array}{l}1 \\
3\end{array}$ & $\begin{array}{l}76 \\
73\end{array}$ & $\begin{array}{l}90 \\
72\end{array}$ & $\begin{array}{l}3 \\
3\end{array}$ \\
\hline III & 4 & $\begin{array}{l}\text { P-GH } \\
\text { P-GH } \\
\text { P-GH } \\
\text { P-GH } \\
\text { ACTH }\end{array}$ & $\begin{array}{r}6 \\
6 \\
*) \\
12 \\
12\end{array}$ & $\begin{array}{r}1 \\
10 \\
25 \\
1 \\
3\end{array}$ & $\begin{array}{l}79 \\
81 \\
78 \\
78 \\
81\end{array}$ & $\begin{array}{c}89 \\
88 \\
*) \\
95 \\
79\end{array}$ & $\begin{array}{l}3 \\
3 \\
3 \\
3 \\
3\end{array}$ \\
\hline IV & 4 & $\begin{array}{l}\text { P-GH } \\
\text { P-GH }\end{array}$ & $\begin{array}{r}6 \\
12\end{array}$ & $\begin{array}{l}1 \\
1\end{array}$ & $\begin{array}{l}162 \\
166\end{array}$ & $\begin{array}{l}165 \\
171\end{array}$ & $\begin{array}{l}2 \\
3\end{array}$ \\
\hline
\end{tabular}

*) 2 of the 3 rats died after the first administration of the dose

$\mathrm{H}-\mathrm{GH}$ : human growth hormone

P-GH: porcine growth hormone

ACTH: Corticotrophin (porcine)

hand, increase in body weight in rats of group IV, which had been hypophysectomized at a weight of $170 \mathrm{~g}$, was relatively lower. Human as well as porcine growth hormone $(1 \mathrm{mg} / \mathrm{kg} /$ day) showed similar effects on growth in hypophysectomized rats (group II and III). The tenfold increased daily dose of growth hormone was not more efficatious than the lower dose (group III).

The width of the epiphyseal cartilage (mean values of group III) in hypophysectomized, untreated rats amounted to $145 \mu \mathrm{m}$. After administration of growth hormone for 6 days, it was found to be 243 and $266 \mathrm{um}$ (1 and $10 \mathrm{mg} / \mathrm{kg} /$ day, respectively), after 12 days (1 $\mathrm{mg} / \mathrm{kg} /$ day) $240 \mu \mathrm{m}$. On the other hand, following administration of ACTH for 12 days, the epiphyseal width measured $135 \mu \mathrm{m}$. tomized at a weight of $80 \mathrm{~g}$ (groups I, II and III), pretreatment with growth hormone for 6 days in both low and high dosage (1 or $10 \mathrm{mg} / \mathrm{kg} /$ day) did not increase insulin secretion which had been reduced after hypophysectomy. On the other hand, normalization was observed in these 3 groups after a substitution for 12 days $(1 \mathrm{mg} / \mathrm{kg} /$ day). In rats which had been hypophysectomized at a weight of $170 \mathrm{~g}$ (group IV), however, this normalization had already been reached after 6 days of substitution. Treatment with ACTH for either 6 or 12 days did not improve the response of isolated islets to glucose administration.

Estimation of insulin secretion during the studies of insulin biosynthesis was in agreement with these results (Fig. 2). It can be seen in Fig. 2 that growth hormone administration for 12 days did not only improve the amount but also the rate of insulin release. 


\section{Insulin biosynthesis}

At a glucose concentration of $50 \mathrm{mg} \%$ incorporation of ${ }^{3} \mathrm{H}$-leueine into proinsulin and insulin was very low. No significant differences were observed between also ineffective. In islets obtained from animals of group IV, however, a significant increase of leucine incorporation was observed after 6 days of treatment (1 $\mathrm{mg} / \mathrm{kg} / \mathrm{day})$. On the other hand, administration of

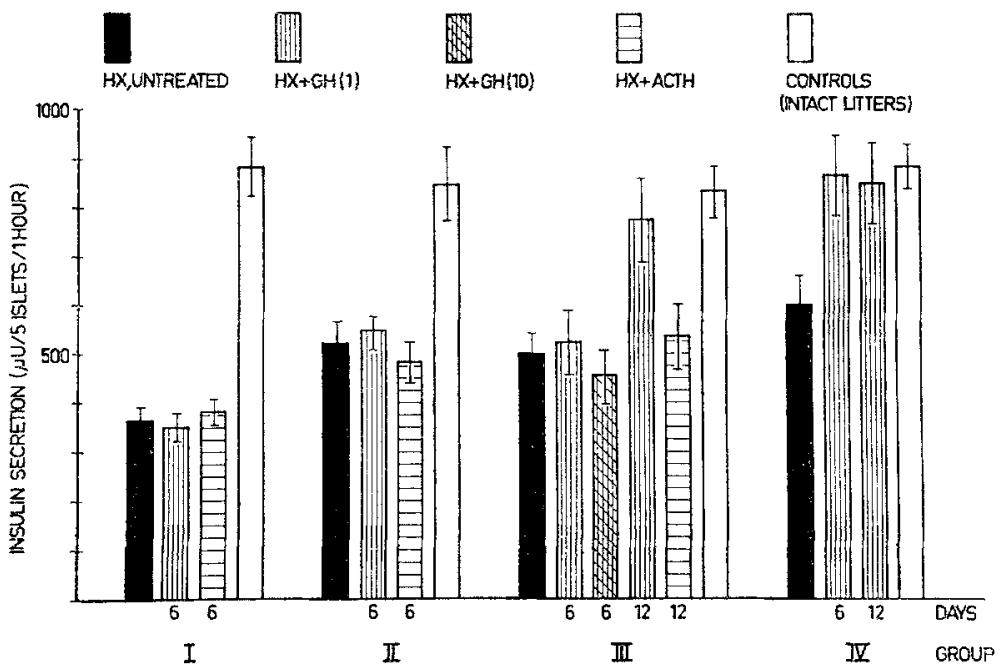

Fig. 1. Insulin secretion of 5 isolated pancreatic islets in the presence of $300 \mathrm{mg} \%$ glucose during $1 \mathrm{~h}$ in $4 \mathrm{groups}$ (I-IV) of hypophysectomized rats (HX) before and after substitution with growth hormone (GH) and ACTH for 6 or 12 days. Mean $+\mathrm{SEM}, \mathrm{n}=9-18$

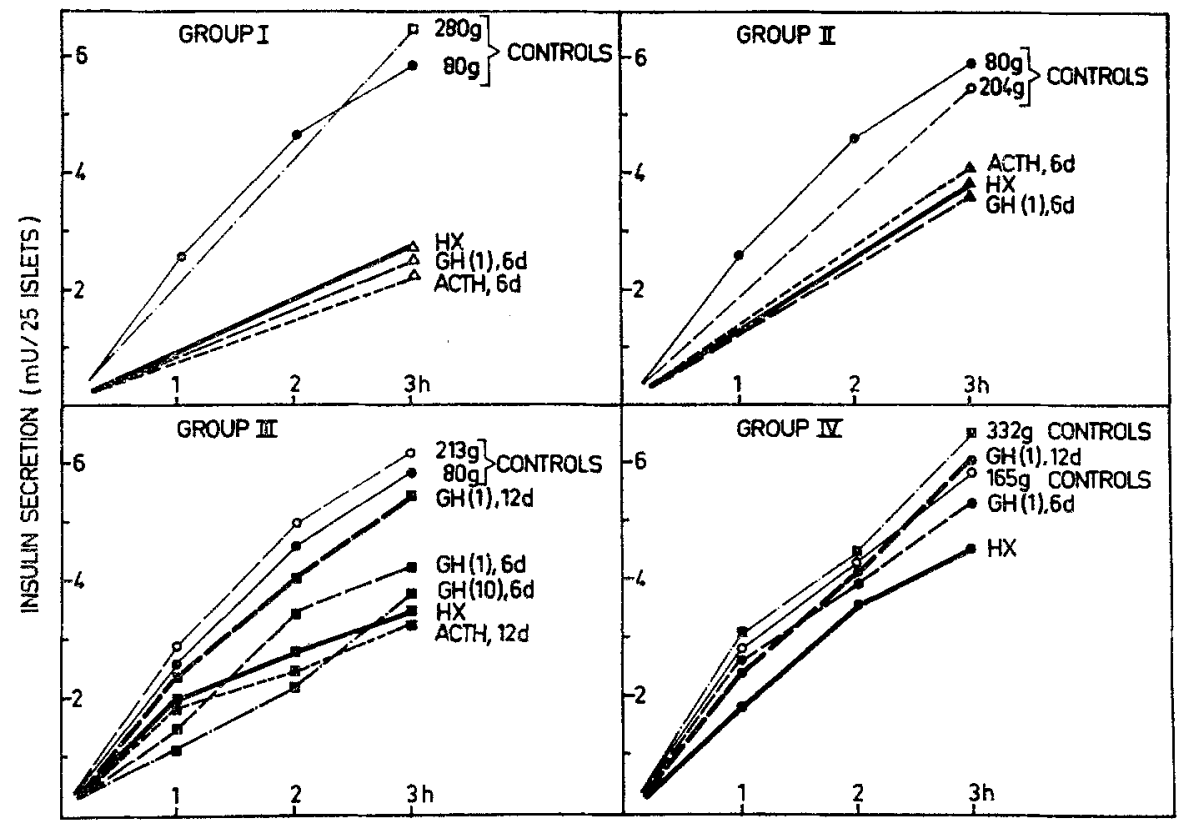

TIME OF INCUBATION (HOURS)

Fig. 2. Insulin secretion of 25 isolated pancreatic islets in the presence of $300 \mathrm{mg} \%$ glucose during $3 \mathrm{~h}$ in 4 groups $(\mathrm{I}-\mathrm{IV})$ of hypophysectomized rats before and after substitution with growth hormone $\mathrm{GH}$ (mg/kg/day) and ACTH for 6 or 12 days (d). Control rats were of both same age and weight. Mean values of $3-6$ experiments

any of the groups of animals. In the presence of 300 $\mathrm{mg} \%$ glucose the incorporation of radioactivity, reduced after hypophysectomy, was not improved after treatment with growth hormone for 6 days in group I-III. The large doses of $10 \mathrm{mg} / \mathrm{kg} /$ day were growth hormone for 12 days ( $1 \mathrm{mg} / \mathrm{kg} /$ day) improved the incorporation of radioactivity into the proinsulin and insulin fraction (group III and IV). In group IV, there were no longer significant differences with normal control rats (Fig. 3). 
Insulin content

No significant changes in the insulin content of the isolated islets were observed in any group or subgroup during the course of therapy. with growth hormone. From the results in rats of group IV it appears that pituitary ablation leads to less severe disturbances when it is performed in later life. As regards insulin biosynthesis, however, final
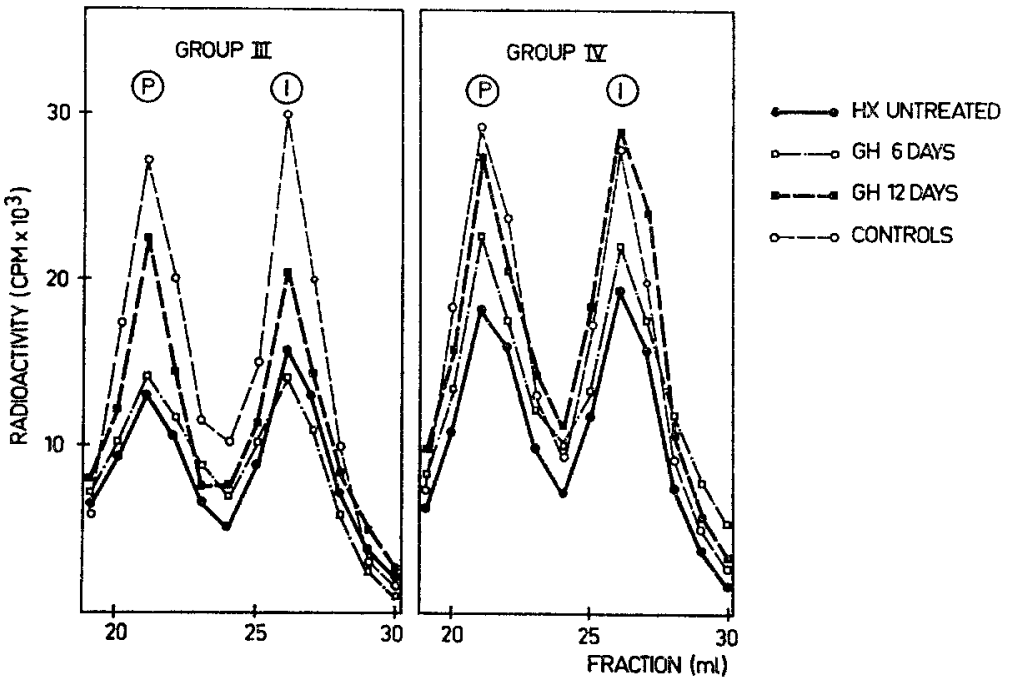

Fig. 3. Radioactivity incorporated into proinsulin (P) and insulin (I) after incubation of 25 isolated pancreatic islets in the presence of $300 \mathrm{mg} \%$ glucose and ${ }^{3} \mathrm{H}$-leucine for $3 \mathrm{~h}$. Fractionation of the islet proteins on a Sephadex $\mathrm{G} 50$ fine column, $0.9 \times 55 \mathrm{~cm}$, fractions of $1 \mathrm{ml}$. Immunologically measurable insulin was determined both in each fraction and in the pooled peaks. Radioactivity was compared based on the insulin content of the islets. Results obtained in hypophysectomized rats (group III and IV) before and after substitution with growth hormone (GH) for 6 days (1 or $10 \mathrm{mg} / \mathrm{kg} / \mathrm{day}$ ) and 12 days $(1 \mathrm{mg} / \mathrm{kg} /$ day $)$. Mean values of $3-6$ experiments

\section{Discussion}

In hypophysectomized rats, human as well as porcine growth hormone were similarily effective on body weight. It appears from our results that, as no differences existed between daily doses of 1 and $10 \mathrm{mg} / \mathrm{kg}$, it is the duration of substitution rather than the total dose administered, which is of significance in relation to the effect on growth. On the other hand, the interval following hypophysectomy (12 or 4 weeks) had no influence on the growth response to this hormone. In clinical analogy, hypopituitary dwarfs with uncalcified epiphyseal cartilages respond to an adequate substitution of growth hormone even late in life.

Genuine growth of the skeleton due to administration of growth hormone was shown on the epiphyseal cartilage of the tibia. No quantitative differences with regard to dose and duration of substitution were, however, demonstrable.

The improvement of secretion and biosynthesis of insulin in isolated islets was also found to be highly dependent on the duration of the substitution with growth hormone. For normalisation, a prior substitution of relatively long duration was necessary. This finding is in agreement with previous observations (in vivo) on insulin secretion in dogs [11] and on glucose tolerance in rats [10]. 9 and 6 however, described positive effects in vitro after only 3 or 4 days of substitution interpretation of our labelling experiments awaits studies on the intracellular leucine pool under the various conditions.

The fact that no change in insulin content was observed after substitution with growth hormone might be ascribed to the use of isolated islets for our experiments [13].

In studies on the liver $[5,2]$ and muscle tissue $[3,4$, 7] it has been demonstrated that hypophysectomy reduces protein synthesis, which can be restored to normal by substituting growth hormone to the animal or by addition of growth hormone to the incubation medium. Therefore, the question arises as to whether our findings concerning insulin biosynthesis merely reflect the effects of growth hormone on protein synthesis in general. Since procedures for extraction of insulin were not included in our experiments, the first radioactivity peak eluting with the void volume of the Sephadex column represented the islet proteins differing from proinsulin, insulin and also differing from material reacting with antibodies to glucagon (unpublished results). Incorporation of ${ }^{3} \mathrm{H}$ leucine into the first peak was found to be increased to $180-200 \%$ at a concentration of $300 \mathrm{mg} \%$ glucose as compared with the values at $50 \mathrm{mg} \%$ glucose [14]. Changes in radioactivity of the first protein peak after hypophysectomy or substitution were almost in parallel with the changes of the proinsulin and insulin peak. However, contamination of the islet preparation with acinar tissue results in increased radioactivity of 
this first peak. In addition, a second peak appears, eluting between the first peak and proinsulin. That it is acinar tissue which may also account for such a second peak, has been proved by fractionating exocrine pancreatic tissue which had been incubated in the absence of islets. Therefore, as regards the first peak, conclusions concerning protein synthesis in general should be drawn with eaution, so that the question cannot definitely be answered whether biosynthesis of insulin is specifically influenced by growth hormone or not. However, in our studies we found that secretion of insulin was improved or normalized by the administration of growth hormone. As it was the secretion of insulin which was first increased it can be concluded that improvement of insulin secretion was not a consequence of improved synthesis of insulin. On the other hand, a relationship between glucosestimulated secretion and synthesis of insulin is evident. Thus, growth hormone appears to influence the pancreatic B-cell by maintaining its sensibility to glucose both with regard to secretion and biosynthesis of insulin.

Administration of ACTH was effective only in vivo: an increase of lowered levels of blood sugar was found. This may be ascribed to its action on the adrenal cortex $[12,8]$. No effects were observed in vitro. Although the possibility that ACTH was administered in an inadequate mode or dose cannot be ruled out, it might be assumed that $\mathrm{ACTH}$, unlike growth hormone, has no direct long-term effect on the function of the pancreatic B-cell.

\section{Literature}

1. Baetzner, P., Fehm, H.L., Voigt, K.H., Schleyer, M., Pfeiffer, E.F.: Measurement of biological activity in various growth hormone preparations using a modified tibia test. Acta endocr. 70, 231-238 (1972).

2. Korner, A.: Growth hormone control of biosynthesis of protein and ribonucleic acid. Recent Progr. Hormone Res. 21, 205-240 (1965).

3. Kostyo, J.L., Knobil, E.: The effect of growth hormone on the in vitro incorporation of leucine-2- $\mathrm{C}^{14}$ into the protein of rat diaphragm. Endocrinology 65, $395-401$ (1959) a.

4. Kostyo, J.L., Knobil, E.: The stimulation of leucine-C ${ }^{14}$ incorporation into the protein of isolated rat diaphragm by simian growth hormone added in vitro. Endocrinology 65, 525-528 (1959) b.

5. Li, C.H., Simpson, M. E., Evans, H.M.: The growth of hypophysectomized female rats following chronic treatment with pure pituitary growth hormone. II. Some chemical components of the musculature, liver and blood plasma. Growth 13, 171-174 (1949).

6. Malaisse, W., Malaisse-Lagae, F., King, S., Wright, P. H.: Effect of growth hormone on insulin secretion. Amer. J. Physiol. 215, 423-428 (1968).

7. Manchester, K. L., Young, F. G.: Hormones and protein biosynthesis in isolated rat diaphragm. J. Endocr. 18, 381-394 (1959).

8. Marco, M., Melani, F., Goberna, R., Rott, W. H., Pfeiffer, E.F.: Einfluß der Prednisolonbehandlung auf die Insulinsekretion der Ratte. Diabetologia 4, 365-369 (1968).

9. Martin, J.M., Gagliardino, J. J. : Effect of growth hormone on the isolated pancreatic islets of rat in vitro. Nature (Lond.) 213, 630-631 (1967).

10. Penhos, J.C., Castillo, L., Voyles, N., Gutman, R., Lazarus, N., Recant, L. : Decreased glucose tolerance in the rat following hypophysectomy. Endocrinology 88, 1141- 1149 (1971).

11. Pfeiffer, E. E.: Wachstumshormon und Insulinsekretion: Die Verhältnisse unter normalen und pathologischen Bedingungen. In: Wachstumshormon und Wachstumsstörungen, p. $41-54$ 1965. 11. Symposium der Deutschen Gesellschaft für Endokrinologie, Düsseldorf 1964. E. Klein, Editor. Berlin-Göttingen-Heidelberg: Springer Verlag.

12. Renauld, A., Pinto, J.E.B., Florin Christensen, A., Sverdlik, R.C., Foglia, V.G.: Serum immunoreactive insulin in the hypophysectomized dog. Effect of cortisol replacement therapy. Horm. Metab. Res. 2, 157-160 (1970).

13. Schatz, H., Abdel Rahman, Y., Hinz, M., Fehm, H.L., Nierle, C., Pfeiffer, E.F.: Hypophysis and function of pancreatic islets. I. The influence of hypophysectomy on insulin secretion and biosynthesis of proinsulin and insulin in isolated pancreatic islets. Diabetologia 9, $135-139(1973)$.

14. Schatz, H., Maier, V., Hinz, M., Nierle, C., Pfeiffer, E. F.: Stimulation of ${ }^{3} \mathrm{H}$-leucine incorporation into the proinsulin and insulin fraction of isolated pancreatic mouse islets in the presence of glucagon, theophylline and eyclic AMP. Diabetes 22 , in press (1973).

15. Schleyer, M., Schröder, K.E., Hinz, A.: Comparative investigations of different human growth hormone preparations. Horm. Metab. Res. 2, 174-180 (1970).

16. Schleyer, M.: Preparation of porcine growth hormone. In preparation (1973).

17. Schmidt, F. H.: Die enzymatische Bestimmung von Glucose und Fruktose nebeneinander. Klin. Wischr. 39, $1244-1247$ (1961).

Dr. H. Schatz

Zentrum f. Innere Medizin

und Kinderheilkunde

Steinhövelstr. 9

D-79 Ulm

Federal Republic of Germany 